\title{
Coyote Predation on Sheep, and Control by Aversive Conditioning in Saskatchewan
}

\author{
D.E. JELINSKI, R.C. ROUNDS AND J.R. JOWSEY
}

\section{Abstract}

A study was conducted in 1975 and 1976 to assess domestic sheep (Ovis aries) losses to coyotes (Canis latrans) and evaluate the effectiveness of lithium chloride ( $\mathrm{LiCl}$ ) for controlling depredation In Saskatchewan. Nineteen seventy-five was a control year during which no program of aversive conditioning was in place. In 1976, lithium chloride was introduced as a taste aversion producing agent in treated baits and carcasses at 16 sites. Results were collected through personal interviews with cooperators and by means of mail-in questionnaires. Total lamb and sheep mortality attributed to coyotes within the monitored flocks was $4.0 \%$ in 1975 and $1.5 \%$ in 1976. Coyotes preyed on lambs $90 \%$ of the time in 1975 and $78 \%$ in 1976. In 1975 coyotes killed 802 lambs and 80 adult sheep in the monitored flocks. Within the total flock population, lamb losses were $3.6 \%$ and adult sheep losses were $0.4 \%$. In 1976 coyotes killed 223 lambs, (2.3\% of lambs) and sheep losses remained relatively stable at 78 ( $0.7 \%$ of adults). Lamb losses comprised $1.1 \%$ of the total flock population, and adult sheep losses $0.4 \%$. During a period of relatively stable pricing, monetary losses were estimated at $\$ 41,195.34$ in 1975 and $\$ 11,531.00$ in 1976. The concurrence of lethal and other nonlethal coyote control measures, together with absence of coyote demographic data, precludes the unequivocal statement that the $66 \%$ reduction in predation was caused by $\mathrm{LiCl}$ treatment, but we suggest that $\mathrm{LiCl}$ was a major influence.

The livestock industry on the North American plains has advocated reduction of coyote (Canis latrans) populations primarily because of predation on domestic sheep (Ovis aries). The biosocioeconomic aspects of coyote control are complex and decisions concerning predator control often are based on emotion rather than objective information. Problems associated with objectively evaluating the situation are both philosophical and practical (McCabe and Kozicky 1972). Rounds (1980) points out that it is problematic to accurately assess the economic ramifications of wildlife presence from both positive and negative points of view. Equally important are ecological implications (Craighead and Craighead 1956). The Cain Report (Cain et al. 1972) and subsequent research have met with limited success in attempting to address predation problems.

Gustavson et al. (1974) hypothesized that if coyotes eat baits treated with an illness inducing drug (lithium chloride) they will associate the taste of meat with subsequent gastrointestinal discomfort and will generalize (transfer) this association to live anim-

\footnotetext{
Authors are Departments of Geography and Zoology, Brandon University, current address Department of Geography, University of Calgary, Calgary. Alberta, Canada T2N IN4; professor, Department of Geography, Brandon University, Brandon, Manitoba, Canada R7A 6A9; and Problem Wildlife Specialist, Animal Industry Branch, Saskatchewan Agriculture, Regina, Saskatchewan, Canada S4S 0BI.

R.E. Lind and T.W. Rock made helpful comments during the preparation of the manuscript. We are indebted to $R$. Sparling who helped in many ways during the study, and gratefully acknowledge the cooperation of participating sheep producers and pasture managers, J. Koal, and personnel of Saskatchewan Agriculture and the Saskatchewan Department of Tourism and Renewable Resources.

Manuscript received October 30, 1981.
}

als, thus suppressing predatory attacks. They developed aversion in captive coyotes when intraperitoneal injections of $\mathrm{LiCl}$ followed consumption of bait. Further studies (Gustavson et al. 1976) found that this condition could be established using $\mathrm{LiCl}$ in baits or carcasses of selected prey.

Gustavson et al. (1974, 1976, 1977, 1982) advocated use of $\mathrm{LiCl}$ treated baits as a method of reducing domestic sheep losses to coyotes and presented preliminary data on the success of $\mathrm{LiCl}$ as a taste aversion producing agent in Saskatchewan (Gustavson et al. 1977). This paper re-assesses the technique using the Saskatchewan data base and examines the magnitude of sheep losses among some producers experiencing severe depredation in Saskatchewan.

Five sheep management systems are operative in Canada: (1) range flock, (2) farm flock, (3) total confinement, (4) controlled environment, and (5) lamb feedlot (Agriculture Canada 1976). Range flocks are located in the prairie provinces and are most vulnerable to predators (U.S. Department of Interior 1978). Farm flocks are the most common sheep management operation in Canada (Agriculture Canada 1976), and losses to predators are generally lower with this type of management (Dorrance and Roy 1976). Total confinement, controlled environment, and feedlot enterprises usually do not experience losses to predators but are labor intensive and costly (Agriculture Canada 1976). Dorrance and Roy (1976), however, found that when predation did occur in confined flocks, it was particularly severe because the situation allows the predator an opportunity to kill a large number of sheep.

\section{Methods}

Data concerning coyote depredation on domestic sheep in Saskatchewan was collected through personal interviews and by mailin questionnaire in 1975 and 1976. Participating producers were those who had contacted the Problem Wildlife Unit (Saskatchewan Agriculture's Animal Industry Branch) either directly, or indirectly through livestock specialists or agricultural representatives, and who were thought to be experiencing unusually severe depredation problems. The sample, therefore, is not random. Producers were asked to respond to questions concerning the number of sheep on hand, losses of stock, cause(s) of loss, type(s) of coyote control employed and past history of depredation.

Most producers, while co-operative, kept poor or no written records, necessitating recall from memory. Possibility of error was admitted by most. Producers often attributed deaths to predation despite the possibility of other causes. In the case of missing sheep the producer was left to surmise the cause of loss. There may be a natural tendency to assume that the same pattern of loss prevails among the unobserved animals as among the observed (Wagner and Pattison 1973). When carcasses were available and not too decomposed we determined whether or not predation had occurred by methods outlined by Davenport et al. (1973). Necropsies were not performed. Preparation and development of baits were described by Gustavson et al. (1982). 
The estimated cash loss of adult sheep and lambs was based on the average value per head of sheep and lambs handled by the Saskatchewan Sheep and Wool Marketing Commission in 1975 and 1976 . It is not practical to account for variations in dollar value of sheep because of health and breed.

Privately owned and community sheep pastures comprised the original 22 sites selected for experimentation with $\mathrm{LiCl}$ as an aversive conditioning agent for controlling coyote predation on domestic sheep in 1975. Six sites were eliminated from analyses because either no sheep were lost to coyotes in 1975, or farmers did not wish to cooperate. Four of the 16 sites were community pastures grazed by several flocks belonging to participating patrons. All sheep in 1 pasture were considered 1 flock. Lithium chloride treated baits were not used in 1975 (control year), but some producers employed other lethal and non-lethal methods of coyote control.

\section{Results}

Flock size and structure varied from 101 to 4,543 sheep (ewes and rams) and lambs (Table 1). Total losses of sheep and lambs to coyotes in 1975 was 892 or $4.0 \%$ of the 22,407 animals. Treated baits were used in 1976 in the same pastures, and coyotes preyed upon 301 of 20,574 sheep and lambs for predation rate of $1.5 \%$. Overall losses, therefore, decreased $66 \%$ when $\mathrm{LiCl}$ was used (Table 1).

Coyotes were suspected of killing 802 lambs and 80 adult sheep in 1975 (Table 1). Lamb losses constituted $7.3 \%$ of all lambs and adult sheep losses accounted for $0.7 \%$ of the adult population in monitored flocks. In 1976 lamb losses decreased to 223 or $2.3 \%$ of the total lamb population. Sheep losses remained relatively stable at 78 or $0.7 \%$ of the total number of adult sheep. Coyotes preyed on lambs in $89.9 \%$ of the cases in 1975 and $74.2 \%$ in 1976 . Ten kills were not identified as to age of animal.

Prices per head of sheep remained relatively stable between years (lambs \$41.27, 1975, and \$41.60, 1976; sheep \$24.40, 1975, and $\$ 28.90$, 1976; Sask. Sheep and Wool Marketing Comm., pers. comm.). The estimated value of sheep lost in 1975 was $\$ 41,195.34$ compared to $\$ 11,531.00$ in 1976 . Losses varied among study sites in both number and estimated values.

Attitudes towards coyote control were surveyed in 1980. Producers were asked if they were in favor of controls on hunting, trapping, and predator control programs. Nineteen respondents indicated yes, and two answered no. Nearly all landowners, there- fore, do not favor extermination of coyotes.

\section{Discussion}

Several problems arise in assessing $\mathrm{LiCl}$ as a coyote damage control technique. First, co-operators were advised to employ other coyote control measures such as confinement of small lambs, disposal of carrion and use of traps and snares while using $\mathrm{LiCl}$. Most producers, however, were lax in using alternative measures when $\mathrm{LiCl}$ was introduced. Nevertheless, it is impossible to attribute changes in depredation rates to a single control measure. Second, one must assume that predation rates remain constant. Third, since loss estimates were not based on actual counts by the investigators, producers may over-estimate losses in hopes that a compensation program would be initiated if losses appeared severe. Fourth, it was nccessary in most cases to rely on the producer to diagnose cause of death. It is possible that animals died of other causes and that coyotes fed upon carcasses as carrion.

Rock (1976) recorded losses of sheep to coyotes between 1970 and 1974 at a community pasture in southwestern Saskatchewan (Site 16, Table 1). Predat or losses ranged from $0.7 \%$ to $2.7 \%$ of the total flock among years. This pasture was used for an intensive coyote program relying heavily on the use of Compound 1080 (sodium monofluoroacetate). Loss of ewes ranged between $0.2 \%$ and $0.5 \%$ for the period 1970 to 1975 , the lamb losses ranged from $1.2 \%$ to $5.9 \%$ for the same period. Necropsies were performed during 3 of the 5 years and predation losses closely approximated non-predation losses in most years.

Dorrance and Roy (1976) estimated domestic sheep losses to predators in Alberta in 1974 by personal interviews with $5 \%$ of the membership of the Alberta Provincial Sheep Breeders Association. Producers attributed $88 \%$ of predation losses to coyote resulting in a calculation of $1.4 \%$ coyote-caused ewe losses and $2.5 \%$ coyote-caused lamb losses.

The percent of lambs and sheep lost to various causes in 15 American Western States in 1974 was reviewed by Gee et al. (1977). Coyotes preyed upon an average of $2.5 \%$ of the adult sheep and $8.1 \%$ of the lambs in monitored flocks.

Reynolds and Gustad (1971) reported a 5.3\% loss of sheep to coyotes for the states of Montana, Wyoming, Colorado, and Texas. Nielson and Curle (1970) reported 6.1\% loss in Utah apd Early et al. (1974) estimated $3.4 \%$ for Idaho. During these years predator control programs relied heavily on the use of toxicants (Wagner 1972) until use was banned in 1972.

Table 1. Flock structure and absolute mortality of sheep lost to coyotes in 1975-1976 on lithium chloride field trial sites in Saskatchewan. ${ }^{1}$

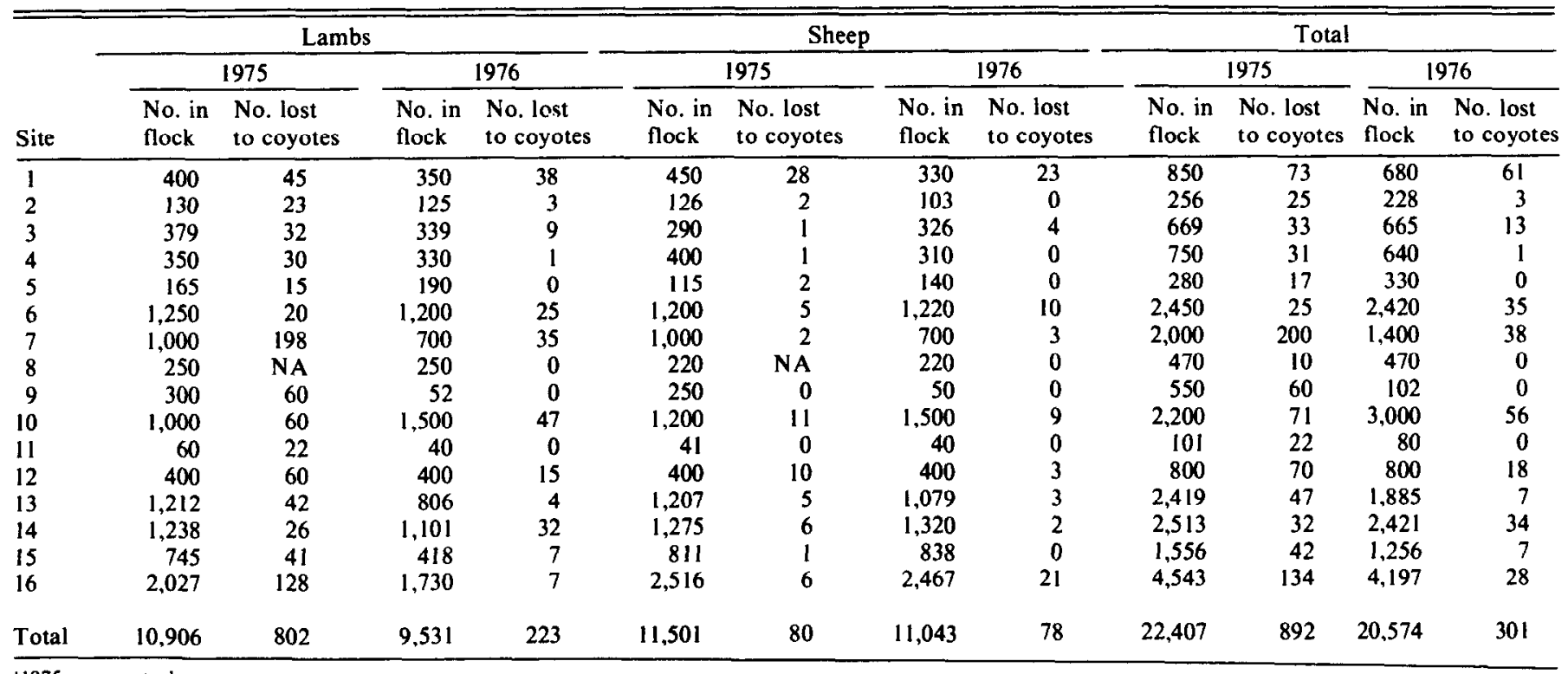

11975 was control year. 
Suspected predation losses on our sites were $<1.0 \%$ of the tota adult sheep pastured in both 1975 and 1976, Coyotes preyed upon $7.4 \%$ of the pastured lambs in 1975 and $2.3 \%$ in 1976. Other studies clearly indicate that lambs are selected by coyotes more often than adult sheep (Nielson and Curle 1970, Dorrance and Roy 1976, Rock 1976). Our estimated losses, therefore, fall within the values reported on other ranges.

Despite the possibility of producer bias and the lack of experimental controls, we believe that the $66 \%$ reduction in predation losses between 1975 and 1976 on our sites can be attributed in part to the use of $\mathrm{LiCl}$. Cumulatively, 4 field evaluations in 3 widely separated geographic locations (including this study) resulted in a $60 \%$ reduction in sheep losses to coyotes (Gustavson et al. 1976, 1977, Ellins et al. 1977).

The methods and interpretation of similar field trials have been criticized (Griffiths et al. 1978, Sterner and Shumake 1978, Conover et al. 1979, Burns 1980). Major problems concern variation in ranching operations and coyote abundance, availability of alternative prey, the fact that other control measures are used in conjunction with $\mathrm{LiCl}$, and the possibility of creating aversion to the chemical rather than to the prey. In combination these factors obscure results and make accurate interpretation difficult. Since we encountered these problems, the observed decrease in predation cannot unequivocally be attributed to the use of $\mathrm{LiCl}$. We believe, however, that the reduction in predation represents too substantial a change not to suggest $\mathrm{LiCl}$ as a major influence.

The ecological advantages of adversive conditioning lie in the fact that resident coyotes are not removed from established territories. Territorial behavior is strong among coyotes (Camenzind 1978), and although local populations will wander (Hibler 1977, Wade 1978), they return to home areas and exclude conspecifics from established territories. If local populations can be conditioned to avoid sheep, their continued presence should decrease immigration of non-conditioned coyotes. Carrying capacity is maintained by dispersal of young coyotes (U.S. Department of Interior 1978), leaving conditioned adults on ranges.

Studies investigating factors limiting coyote populations have identified food as the predominant constraint (Murie 1940, Gier 1968, Clark 1972, Wagner 1972, Nellis and Keith 1976, Weaver 1977). Sheep are not inherently recognized as prey (Lehner 1976), but regular exposu re to small lambs or carcasses results in learned killing (U.S. Department of Interior 1978). Removal of carrion, therefore, should be practiced in conjunction with aversive conditioning to insure best results (Todd and Keith 1976).

Predation can cause substantial financial loss. The magnitude of losses to individual producers, however, is not adequately reflected by computing average loss figures. The producer may feel either that loss incurred is equivalent to total fall market value, or that it equals the monetary value to replace the animal. Nielson and Curle (1970) suggest that the loss of a lamb represents economic profit which equals the dollar value of the lamb at market time minus the average cost of production. This results in reducing the marketable crop which increases the average cost of raising each lamb to a marketable weight. They also suggest that when a ewe is killed, the producer losses the market value of the ewe, and, in some cases, the lamb also dies. Appraisal of coyote-livestock interactions is complex and requires more than a short-term study. If $\mathrm{LiCl}$ can reduce loses as substantially as our data suggest the result is considerable savings to the sheep producer.

Most producers interviewed in 1980 believed that coyotes have appreciable value in the ecosystem. They realized the beneficial aspects of coyotes in controlling rodents (Gier 1968, Mathwig 1973), their aesthetic value, and importance as a fur bearer. This attitude was usually coupled with a statement suggesting that when predation "gets out of hand, coyotes should be controlled." Most were receptive towards the concept of using aversive conditioning for coyote control and were further convinced by observing changes in predation within their flocks.

We do not view aversive conditioning as either the single best method to reduce livestock losses to predators, or as an inferior method of field control. Studies clearly indicate that a combination of preventive measures may assure best results. Cost factors relating to the type of husbandry practiced and severity of predation ultimately determines the feasibility of various methods. Livestock producers are interested in reducing losses as quickly and inexpensively as possible. The use of a variety of control methods will obviate attributing success to any single method. The advantages of aversive conditioning are that it is inexpensive and ecologically sound. Predators are not removed from the ecosystem and nontarget species are not destroyed.

\section{Literature Cited}

Agriculture Canada. 1976. Sheep production and marketing. Pub. 1582 Canada Dep. Agr., Ottawa, Ont. 54 p.

Burns, R.J. 1980. Evaluation of condition predation aversion for controlling coyote predation. J. WildI. Manage. 44:938-942.

Cain, S.A., J.A. Kadlec, D.L. Allen, R.A. Cooley, M.G. Hornocker, A.S. Leopold, and F.H. Wagner. 1972. Predator control-1971-report to the Council on Environmental Quality and the Department of the Interior by the Advisory Committee on Predator Control. Inst. for Environmental Quality, Univ. Mich., Ann Arbor. 107 p.

Camenzind, F.J. 1978. Behavioral ecology of coyotes on the National Elk Refuge, Jackson, Wyoming. p. 267-296. In: M. Bekoff (Ed.), Coyotes: Biology, Behavior and Management. Academic Press, N.Y. 384 p.

Clark, F.W. 1972. Influence of jack rabbit density on coyote population change. J. Wildl., Manage. 36:343-356.

Conover, M.R., J.E. Francik and D.E. Miller. 1979. Aversive conditioning in coyotes: a reply. J. Wildl. Manage. 43:209-211.

Craighead, J.J., and F.C. Craighead. 1956. Hawks, owls, and wildlife. Stackpole, Harrisburg, Penn. (Reprinted: Dover, New York. 1969). 443 p.

Davenport, J.W., J.E. Bowns and J.P. Workman. 1973. Assessment of sheep losses to coyotes. Res. Rep. 7, Agr. Exp. Sta., Logan, Utah, 17 p.

Dorrance, M.J., and L.D. Roy. 1976. Predation losses in Alberta. J. Range Manage. 29:457-460.

Early, J.O., R.C. Roetheli, and G.R. Brewer. 1974. An economic study of predation in the Idaho range sheep ind ustry, 1970-71 production cycle. Idaho Agr. Res. Progr. Rep. No. 182. Boise. 49 p.

Ellins, S.R., S.M. Catalano, and S.A. Schechinger. 1977. Conditioned taste aversion: a field application to coyote predation on sheep. Behav. Biol. 20:91-95.

Gee, C.K., W.R. Bailey, R.L. Gum, and L.M. Arthur. 1977. Sheep and lamb losses to predators and other causes in the United States. Agr. Econ. Rep. 369, USDA Econ. Res. Serv., Washington, D.C. 41 p.

Gier, H.T. 1968. Coyotes in Kansas (reviesed). Kansas State Coll. Agr. Exp. Sta. Bull. 393.118 p.

Grifriths, R.E., Jr., G.E. Connolly, R.J. Burns, R.T. Sterner. 1978. Coyotes, sheep and lithium chloride. Proc. Veriebrate Pest. Conf. 8: 190196.

Gustavson, C.R., J. Garcia, W.G. Hankins, and K.W. Rusinick. 1974. Coyote predation control by aversive conditioning. Science 184:581-583.

Gustavson, C.R., D.J. Kelly, M. Sweeney, and J. Garcia. 1976. Preylithium aversions. In: Coyotes and wolves. Behav. Biol. 17:61-72.

Gustavson, C.R., J.R. Jowsey, D.N. Millizan, M.J. Sweeney, and R.G. Brewster. 1977. Taste aversion control of coyote predation in Washington, California and Saskatchewan. Paper presented at the annual meeting of the Western Psychological Association, April 1977. Seattle, Wash.

Gustavson, C.R., J.R. Jowsey, and D.N. Milligan. 1982. A 3-year evaluation of taste aversion coyote control in Saskatchewan. J. Range Manage. 35:57-59.

Hibler, S.J. 1977. Coyote movement patterns with emphasis on home range characteristics. M.S. Thesis, Utah State Univ., Logan. 114 p.

Lehner, P.N. 1976. Coyote behavior: Implications for Management. Wildl. Soc. Bull. 4:120-123.

Mathwig, H.J. 1973. Food and population characteristics of lowa coyotes. lowa State J. Res. 47:167-189.

MeCabe, R.A., and E.L. Kozicky. 1972. A position on predator management. J. Wildl. Manage. 36:382-394.

Murie, A. 1940. Ecology of the coyote in the Yellowstone. Fauna Natl. Parks, Bull. No. 4. U.S. Govt. Printing Office, Wash., D.C. 206 p.

Nellis, C.H., and L.B. Ketth. 1976. Population dynamics of coyotes in central Alberta, 1964-68. J. Wildl. Manage. 40:389-399.

Nielson, D.B., and D. Curle. 1970. Predator costs to Utah's range sheep industry. Utah State Univ., Logan. Mimeo. 11 p.

Reynolds, R.N., and O.C. Gustad. 1971. Analysis of statistical data on sheep losses caused by predation in four western states during 1966-69. U.S. Bur. Sport Fisheries Wildl. Mimeo. 20 p. 
Rock, T.W. 1976. Coyote depredation and control study on a community sheep pasture. Saskatchewan Dep. Tourism and Renew. Res. Wildl. Tech. Rep. 76-2. 43 p.

Rounds, R.C. 1980. Beaver depredation on private lands surrounding Riding Mountain National Park. Nat. Res. Inst., NRI-80-1, Univ. Man., Winnipeg. $105 \mathrm{p}$.

Sterner, R.T., and S.A. Shumake. 1978. Coyote damage control research: A review and analysis. p. 297-325. In: M. Bekoff (Ed.). Coyotes: biology behavior and management. Academic Press, New York. 384 p.

Todd, A.W., and L.B. Keith. 1976. Responses of coyotes to winter reductions in agricultural carrion. Alta. Rec., Parks, Wildl., Dep. Fish and Wildl., Div. Wildl. Tech. Bull. No. 5. Edmonton. 32 p.

United States Department of Interior. 1978. Predator damage in the west: A study of coyote management alternatives. U.S. Fish and Wildlife Service, Washington, D.C. 168 p.

CHANGE OF ADDRESS notices should be sent to the Managing Editor, 2760 West Fifth Ave., Denver, Colo. 80204, no later than the first day of the month of issue. Copies lost due to change of address cannot be replaced unless adequate notice is given. To assure uninterrupted service, provide your local postmaster with a Change of Address Order (POD Form 3575) indicating thereon to guarantee forwarding postage for second-class mail.

Statement of Ownership, Management, and Circulation

(Act. of August 12, 1970, Sec. 3685, Title 39, United States Code)

1. Title of Publication: Journal of Range Management

2. Date of Issue: September 9, 1982

3. Frequency of Filing: Bimonthly

4. Location of Office of Publication: 2760 West Fifth Ave., Denver, Colo. 80204

5. Location of General Business Office: Same

6. Name and Address of:

Publisher: Society for Range Management, 2760 West

Fifth Ave., Denver, Colo. 80204

Editor: Patricia Smith 2760 West Fifth Ave.,

Denver, Colo. 80204

Managing Editor: Jan Duck 2760 West Fifth Ave., Denver, Colo. 80204

7. Owner: Society for Range Management, 2760 West Fifth Ave., Denver, Colo. 80204

8. Known Bondholders, Mortgagees, etc.: None

9. For Completion by Nonprofit Organizations Authorized to Mail at Special Rates: The purpose, function, and nonprofit status of this organization and the exempt status for Federal income tax purposes have not changed during preceding 12 months.

10. Extent and Nature of Circulation
A. Total copies printed
B. Paid Circulation
1. Dealers, counter sales
2. Mail subscriptions
C. Total paid circulation
D. Free distribution
E. Total distribution
F. Copies not distributed
G. Total
$6,508 \quad 6,518$

600
5,900
6,500
8
6,508
0
6,508
614
5,896
6.510
8
6,518
6,518

Actual for

12 months filing date
Wade, P.A. 1978. Coyote damage: A study of its nature and scope, control measures and their application. p. 347-368. In: M. Bekoff (Ed.). Coyotes: biology, behavior, and management. Academic Press, New York. $384 \mathrm{p}$.

Wagner, F.H. 1972. Coyotes and sheep; some thoughts on ecology, economic, and ethics. 44th Utah State Univ. Faculty Honor Lecture, Logan Utah. 59 p.

Wagner, F.H., and L.G. Pattison. 1973. Analyses of ex isting data on sheep loss and predator activity. p. 18-35. In: Final report to Four Corners Regional Commission on Predator Control Study Contract FCRC No. 621-366-044.

Weaver, J.L. 1977. Coyote-food base relationships in Jackson Hole, Wyoming. M.S. thesis, Utah State Univ., Logan. 88 p.

\section{Ten years in the making!}

THE NORTHERN

Ecology and Management

DOUGLAS B. HOUSTON, National Park Service

"Sets a high standard of scholarship and science. [The author] has done a good job of sorting through a conflicting array of data that has generated a classic management controversy."- Rlchard S. Miller, School of Forestry and Environmental Studies, Yale University

Important and controversial, this exhaustive study of the northern Yellowstone elk herd and its impact on the northern range ecosystem begins by examining Yellowstone's most controversial question: Was the intentional killing of elk, carried out for several decades, necessary to maintain a wildlife-vegetation equilibrium? Basing his study on scientific observations made over a 150-year period and employing a system of comparative historical photography, research biologist Houston considers the herd's seasonal distribution, its population dynamics, its social behavior, and its relations with carnivores, among other topics. His conclusion, and his several provocative recommendations for the restoration and preservation of Yellowstone, make this volume essential reading for all those interested in environmental planning or the management of our national parks.

474 pages over 160 photographs \#94945 \$48.00

MACMILLAN PUBLISHING CO., INC.

\section{Please clip and mail to:}

Macmillan Publishing Co., Inc.

200D BROWN STREET, RIVERSIDE NJ 08370

Please send me copy(ies) of THE NORTHERN YELLOWSTONE ELK, by Douglas B. Houston (ISBN 0-02-949450-8)@ \$48.00 plus sales tax where required and $\$ 1.50$ per copy shipping and handling. If I am not fully satisfied, I may return the book(s) within 30 days and my money will be refunded. $\square$ Enclosed is my check/money order for $\$$

$\square$ Charge my $\square$ VISA $\square$ MasterCard for $\$$

Acct. \#.

Exp. date:_Bank \# $(M C$ only $)$ :

Signature

(Credit card order not valid without signature)

To place a VISA or MasterCard order, please call 800-223-1001 during normal office hours. In New York, call 212-935-8090.

NAME

ADDRESS

CITY/STATE/ZIP

Price good in continental United States. Alaska, and Hawali only. Publisher's price subject to change without notice.

IC-011

JRM $1 / 83$

1 certify that the statements made by me above are correct and complete.-Jan Duck, Managing Editor. 